\title{
KAJIAN KARAKTER PEMBENTUK LANSKAP BUDAYA MASYARAKAT ADAT KAJANG DI SULAWESI SELATAN
}

\section{Study of Kajang Cultural \\ Landscape Character in South Sulawesi}

Rezky Nur Awalia Mahasiswa Departemen Arsitektur Lanskap, Fakultas Pertanian IPB

\section{Nurhayati HS Arifin}

Staf Pengajar Departemen

Arsitektur Lanskap,

Fakultas Pertanian IPB

\section{Kaswanto}

Staf Pengajar Departemen

Arsitektur Lanskap,

Fakultas Pertanian IPB

\begin{abstract}
Kajang is one of the indigenous communities in the Province of South Sulawesi. Kajang cultural landscape formed as a result of interaction between Kajang comunity and their environment. The problems which occurred in this cultural landscape is the degradation of cultural value. The problem caused by the carelessness of youth Kajang about their cultural heritage. The purpose of this study is to identify the landscape elements that formed the landscape character. The method of study was Landscape Character Assessment. The identification of landscape character refered to 11 elements of landscape according to McClelland et al. (1999). Based on the analysis result, the character of Kajang cultural landscape is traditional settlement with the tripatri zoning which depend on local natural resources (forest and agriculture) with the patuntung as their reliance. Landscape unit that shown strong character are sacred settlement area, sacred forest, and the elements around the settlement area such as ancestors tombs, batu temu gelang, balla tammua, and public well.
\end{abstract}

Keywords: intangible, kajang cultural landscape, landscape assessment, landscape character, tangible

\section{PENDAHULUAN}

Indonesia merupakan negara multikultural dan Sulawesi Selatan merupakan salah satu wilayah provinsi di Indonesia yang memiliki beragam suku dan kebudayaan khas. Sebagai contoh di daerah ini terdapat empat suku bangsa utama (Bugis, Makassar, Toraja dan Mandar), lima kelompok bahasa (Bahasa Bugis, Bahasa Makassar, Bahasa Toraja, Bahasa Mandar dan Bahasa Massenrempulu), serta 24 sub kelompok bahasa daerah (Palengkahu 1971).

Kajang merupakan sub etnis Bugis-Makassar yang terletak di Desa Tana Toa, Kecamatan Kajang, Kabupaten Bulukumba. Permukiman Masyarakat Adat Kajang berpusat di Dusun Benteng yang berjarak \pm 200 km dari Makassar ibukota Provinsi Sulawesi Selatan dan $\pm 56 \mathrm{~km}$ dari ibukota Kabupaten Bulukumba. Masyarakat Adat Kajang mendiami wilayah adatnya secara turun temurun dan dipimpin oleh ketua adat yang disebut Ammatoa (Bapak yang dituakan). Mereka menyebut agamanya sebagai agama Patuntung yang memiliki karakteristik yang khas, yakni agama tanpa kitab suci. Ajaran-ajaran agama Masyarakat Adat Kajang tertuang dalam Pasang yang disebarkan turun-temurun secara lisan (Erawati 2016).

Lanskap Budaya Masyarakat Adat Kajang terdiri atas dua kelompok yang secara adat masuk ke dalam wilayah Ipantarang Embayya dan wilayah Ilalang Embayya. Masyarakat yang tinggal di wilayah Ilalang Embayya mempraktekkan cara hidup sangat sederhana dengan menolak teknologi modern. Masyarakat yang tinggal di wilayah Ilalang Embayya dan mepraktekkan ajaran Pasang disebut masyarakat Kajang Dalam, dengan ciri mengenakan pakaian serba hitam dan tidak memakai alas kaki. Sedangkan masyarakat yang tinggal di wilayah Ipantarang Embayya disebut masyarakat Kajang Luar dan sudah mulai meninggalkan ajaran Pasang.

Saat ini lanskap budaya Masyarakat Adat Kajang telah mengalami degradasi lanskap baik secara biofisik maupun budaya. Hal ini disebabkan oleh pengaruh modernitas dan kurangnya kesadaran pemuda Kajang terhadap pentingnya menjaga warisan budaya. Degradasi lanskap secara biofisik yaitu terdapat beberapa rumah tradisional yang telah mengalami perubahan dari segi penggunaan bahan bangunan dan akses jalan untuk masuk dan keluar ke lanskap budaya Masyarakat Adat Kajang yang sudah diaspal mempermudah masuknya modernitas. Sedangkan secara budaya dapat dilihat pada pola tingkah laku Masyarakat Adat Kajang yang mulai meninggalkan aturan adat. Sebagai contoh, penggunaan pakaian serba hitam yang merupakan ciri khas Masyarakat Adat Kajang perlahan mulai ditinggalkan terkhusus oleh mereka yang masih tergolong muda, kebudayaan menenun yang menandakan kaum perempuan Kajang telah dewasa dan siap untuk hidup mandiri juga sudah mulai ditinggalkan oleh kalangan remaja, pada awalnya peralatan rumah tangga dihasilkan dari kerajinan tangan sendiri namun sekarang perlengkapan tersebut diperoleh dari pasar tradisional. Hal ini akan berdampak pada hilangnya identitas dan nilai budaya yang dimiliki. Penelitian ini bertujuan untuk mengidentifikasi pembentuk karakter lanskap budaya Masyarakat Adat Kajang. Hasil penelitian ini diharapkan dapat menjadi pertimbangan dalam pelestarian lanskap budaya dan pengembangan kawasan. 


\section{AWALIA, NURHAYATI, KASWANTO METODE PENELITIAN}

\section{Waktu dan Lokasi Penelitian}

Penelitian ini dilakukan di Desa Tana Toa, Kecamatan Kajang, Kabupaten Bulukumba, Provinsi Sulawesi Selatan (Gambar 1) dengan ketinggian 150-200 m dpl yang berjarak $\pm 200 \mathrm{~km}$ dari Makassar dan $\pm 56 \mathrm{~km}$ dari Ibukota Kabupaten Bulukumba. Penelitian ini dilaksanakan dari bulan Januari sampai Agustus 2015.

\section{Metode}

Identifikasi karakteristik lanskap budaya Masyarakat Adat Kajang dilakukan dengan metode Landscape Character Assessment (Tudor 2014). Landscape Character Assessment (LCA) adalah proses untuk mengidentifikasi dan mendeskripsikan karakter lanskap. Proses ini menjelaskan kombinasi unik dari elemen dan karakter yang mebuat kekhasan lanskap. Identifikasi karakteristik lanskap budaya merujuk pada sebelas

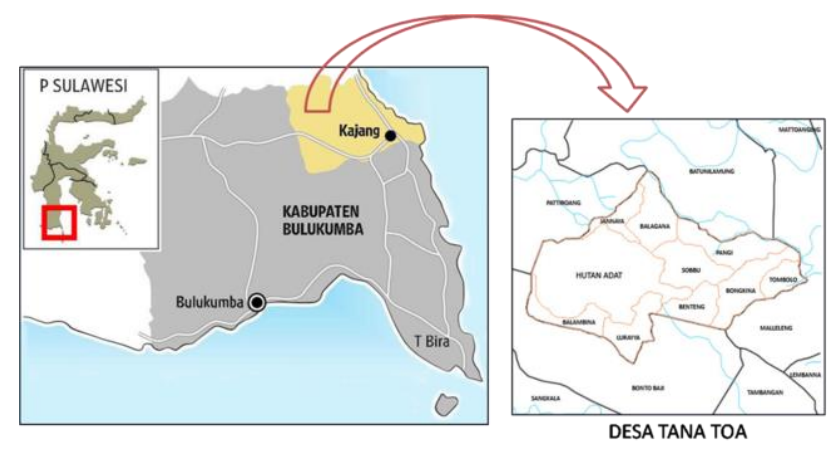

Gambar 1 Lokasi penelitan

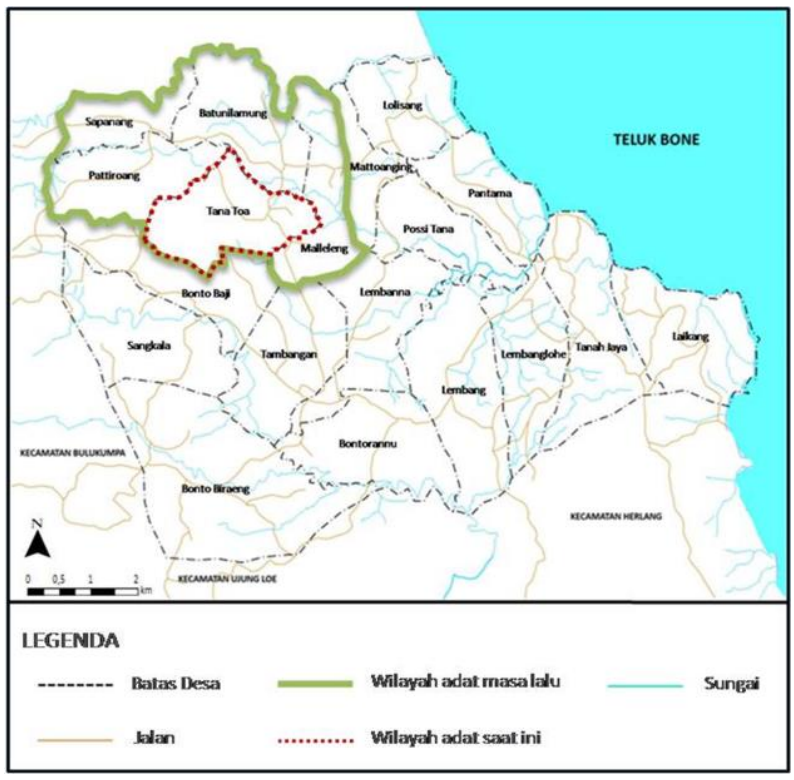

Gambar 2 Batas wilayah lanskap budaya Masyarakat Adat Kajang elemen lanskap yang dikemukakan oleh McClelland et al. (1999). Empat elemen pertama merupakan proses pembentuk lanskap budaya dan bersifat intangible yang terdiri atas landuse dan aktivitas, pola organisasi ruang, respon terhadap lingkungan alam, dan tradisi budaya. Sedangkan tujuh elemen lainnya merupakan komponan fisik pembentuk lanskap dan bersifat tangible. Elemenelemen tersebut terdiri atas jaringan sirkulasi, batas wilayah, vegetasi, bangunan dan struktur, cluster, situs arkeologi, dan elemen skala kecil. Tahapan proses LCA terdiri atas:

1. Tahapan persiapan meliputi penentuan tujuan analisis dan ruang lingkup, seperti: skala objek yang dianalisis, sumber data yang dibutuhkan, dan pihakpihak yang terkait dalam penelitian.

2. Studi pustaka meliputi kegiatan pengumpulan data dan informasi mengenai 11 elemen lanskap yang akan diidentifikasi.

3. Survei lapang meliputi kegiatan pengumpulan data dan informasi mengenai kondisi elemen-elemen lanskap di lokasi studi.

4. Klasifikasi dan Deskripsi. Output dari tahap ini berupa peta dan deskripsi karakter lanskap, serta identifikasi karakteristik kunci.

\section{HASIL DAN PEMBAHASAN}

Karakteristik suatu lanskap budaya dapat dinilai dari dua hal, yaitu elemen fisik (tangible) sebagai komponen fisik pembentuk lanskap dan elemen non-fisik (intangible) sebagai proses yang menjadi instrumen pembentuk lanskap budaya.

\section{Batas Wilayah}

Pada masa lalu lanskap budaya Masyarakat Adat Kajang meliputi Desa Batu Nilamung, Desa Sapanang, Desa Pattiroang, Desa Malleleng, dan Desa Tana Toa. Berdasarkan hasil wawancara dengan Galla Puto juru bicara Ammatoa, wilayah Ilalang Embayya dibatasi oleh empat sungai yaitu: sungai Doro yang berbatasan dengan wilayah Bonto Baji, sungai Limba berbatasan dengan wilayah Batunilamung, sungai Tuli berbatasan dengan wilayah Malleleng, dan sungai Sangkala yang berbatasan dengan wilayah Batunilamung (Gambar 2). Saat ini hanya masyarakat yang bermukim di Desa Tana Toa yang masih melaksanakan adat dan ajaran leluhur mereka. Desa Tana Toa terbagi kedalam sembilan dusun yaitu Dusun Sobbu, Dusun Benteng, Dusun Pangi, Dusun Bongkina, Dusun Tombolo, Dusun Lurayya, Dusun Balambina, Dusun Jannaya, dan Dusun Balagana. Beberapa dusun telah memutuskan untuk menerima bantuan pembangunan berupa jalan aspal dan bantuan pemerintah lainnya. Sejak saat itu wilayah kawasan adat dibagi menjadi dua kelompok yaitu Kajang Dalam (Dusun Sobbu, Dusun Benteng, Dusun Pangi, Dusun Bongkina, Dusun Tombolok, Dusun Lurayya, dan 


\section{AWALIA, NURHAYATI, KASWANTO}

Dusun Balambina) dan Kajang Luar yang terdiri dua dusun (Dusun Jannaya dan Dusun Balagana). Kajang Dalam merupakan wilayah kawasan adat yang masyarakatnya masih melaksanakan ajaran Pasang. Sedangkan Kajang Luar merupakan wilayah kawasan adat yang masyarakatnya sudah mulai meninggalkan ajaran Pasang dan menerima bantuan dari pemerintah berupa pembangunan aspal dan listrik. Pada Dusun Sobbu terdapat sebuah gerbang kawasan adat yang menjadi pembatas antara Kajang Dalam dan Kajang Luar.

\section{Tradisi Budaya}

Masyarakat Adat Kajang menganut kepercayaan Patuntung yang berarti mencari sumber kebenaran. Berdasarkan ajaran Patuntung, untuk mencari kebenaran harus menjalankan tiga pilar hidup yaitu menghormati Turiek Arakna (Tuhan), menghormati tanah yang diberikan Tuhan, dan menghormati nenek moyang. Kepercayaan dan penghormatan terhadap Tuhan merupakan keyakinan yang paling mendasar dalam ajaran Patuntung. Bentuk penghormatan masyarakat Kajang terhadap tanah diwujudkan dengan cara mentabukan penggunaan alas kaki dan setiap 10 tahun sekali masyarakat Kajang mengadakan ritual Andingingi yang bertujuan untuk melestarikan lingkungan, alam dan keseimbangan manusia dengan alam. Masyarakat Adat Kajang juga diwajibkan untuk menghormati nenek moyang atau roh para leluhur yang diwujudkan dengan ritual Pattasi Jera. Selain itu masih terdapat beberapa tradisi budaya lainnya yang masih dilaksanakan oleh masyarakat yaitu budaya bertani, budaya menenun dan berpakaian.

\section{- Budaya Bertani}

Masyarakat Adat Kajang memiliki sistem nilai, norma, dan pengetahuan dalam bertani. Budaya bertani yang dimaksud adalah praktek-praktek Masyarakat Adat Kajang dalam melakukan kegiatan bertani yang sudah menjadi kebiasaan turun temurun. Terdapat beberapa kebiasaan yang dilakukan oleh Masyarakat Adat Kajang dalam bertani, mulai dari persiapan tanam hingga pasca panen. Sebelum memulai persiapan tanam, Masyarakat Adat Kajang melakukan kegiatan A'boja Tanra Allo (mencari hari baik). Kegiatan mencari hari baik ini dilakukan untuk menentukan waktu tanam dan waktu panen dengan cara melihat tanda-tanda atau gejalagejala alam. Setelah penentuan hari baik, selanjutnya dilakukan kegiatan persiapan tanam yang terdiri atas Appassadia Lamungan (menyediakan benih), Angngamme/Ammilei Lamungan (merendam dan memilih benih), A'baju Pabbineang (membuat persemaian) A'taharu Bine (menyemaikan benih), dan A'nangkala (mengolah lahan). Setelah persiapan tanam selesai, selanjutnya dilakukan kegiatan $A^{\prime}$ tanang (menanam). Pada proses penanaman, Masyarakat Adat Kajang melakukan ritual A'baca Doang. Ritual ini bertujuan untuk memohon keselamatan bagi tanaman agar terhindar dari hama dan penyakit yang dapat merusak sehingga menyebabkan kekurangan bahkan kehilangan hasil panen. Sebelum panen Masyarakat Adat Kajang melakukan ritual $A^{\prime}$ patumbu dan ritual ini dilakukan tiga hari sebelum panen.

\section{- Budaya Menenun dan Berpakaian}

Dikehidupan masyarakat Kajang, wanita diwajibkan bisa membuat kain (menenun) dan memasak. Bagi kaum wanita Kajang, menenun merupakan syarat untuk melangsungkan pernikahan. Menenun adalah sebuah budaya dimana prosesnya memiliki ikatan dengan alam. Alat-alat tenun yang digunakan adalah warisan nenek moyang yang terbuat dari bambu dan kayu. Pada umumnya ibu-ibu di kajang menenun di bawah rumah atau biasa juga disebut siring. Proses menenun dilakukan secara tradisional dengan tahapan sebagai berikut:

1. Persiapan warna, daun tarum dan arang direndam selama 3 hari. Rendaman tarum diperas sedangkan abu disaring. Perasan daunt arum dicampur dengan kapur dan diendapkan selama 1 hari. Lalu dicampurkan dengan rendaman abu hingga menjadi warna hitam.

2. A'nyila, proses pencelupan benang dilakuan siang dan sore hari hingga benang menjadi hitam kemudian dijemur hingga kering.

3. Nipaturung, penggulungan benang dalam ganra (alat penggulung benang) membutuhkan waktu 2 sampai 3 hari.

4. Nganne, pada proses ini dibutuhkan waktu sekitar 2 hari untuk menentukan kualitas jenis kain yang dibuat.

5. Attannung, diawali dengan pemberian pattasi pada setiap helai benang menggunakan sabut kelapa. Proses ini membutuhkan waktu 3 sampai 4 hari.

6. Anggarusu, proses pengkilapan kain menggunakan batu $p a^{\prime} g u r u s u$. Proses ini membutuhkan waktu 1 hari dan selanjutnya dijahit menjadi tope le'leng atau passapu.

Dikehidupan sehari-hari, Masyarakat Adat Kajang mengenakan pakaian serba hitam tanpa alas kaki. Pakaian yang digunakan adalah hasil dari tenunan kaum wanita kajang. Berpakaian serba hitam menjadi identitas masyarakat yang bermukim di dalam kawasan adat. Bagi mereka, warna hitam merupakan simbol kesakralan, lambang kesederhanaan, dan persamaan derajat dihadapan Turiek Arakna. Namun saat ini budaya berpakaian tersebut sudah mulai ditinggalkan oleh sebagian warga, terkhusus oleh mereka yang masih tergolong muda.

\section{Respon Terhadap Lingkungan}

Masyarakat Adat Kajang berinteraksi dengan lingkungan sekitarnya bersandar pada ajaran Pasang. Mereka membangun hubungan dengan alam 
AWALIA, NURHAYATI, KASWANTO

berdasarkan ikatan perjanjian dengan Turiek Arakna (Tuhan) untuk menghormati alam yang diwariskan oleh leluhur mereka. Pemahaman tentang hutan sebagai induk kehidupan yang mengatur keseimbangan alam agar terhindar dari bencana. Sehingga dalam memanfaatkan hasil bumi, masyarakat tidak mengeksploitasi secara berlebihan. Setiap orang yang bermaksud mengambil kayu dari hutan untuk membangun rumah harus mendapat izin dari Ammatoa dan harus menanam pohon pengganti untuk menggantikan pohon yang ditebang. Respon Masyarakat Adat Kajang terhadap lingkungan juga dapat dilihat pada pola permukiman. Dengan kondisi topografi yang berbukit, bentuk permukiman diadaptasikan sedemikian rupa sehingga mampu menunjang kehidupan penduduk. Permukiman di posisikan pada lahan yang relatif datar dan dekat dengan sumber daya alam. Halaman rumah biasanya ditanami tanaman fungsional seperti buah-buahan dan tanaman obat.

Lanskap budaya Masyarakat Adat Kajang dikelilingi oleh hutan dengan banyak pepohonan besar dan rumpun bambu. Adanya sumber daya tersebut dimanfaatkan mansyarakat dalam pembangunan rumah. Rumah tradisional Kajang sebagian besar masih menggunakan bahan dasar kayu sebagai tiang, bambu pada bagian dinding, dan daun nipa pada bagian atap. Bentuk respon Masyarakat Adat Kajang terhadap lingkungannya juga dapat dilihat dari arsitektur rumah. Arsitektur rumah tradisional Kajang berupa rumah panggung memiliki fungsi sebagai tempat berlindung dari binatang buas yang berasal dari hutan. Keberadaan hutan keramat juga mempengaruhi arah orientasi rumah dalam kawasan adat. Permukiman dalam kawasan adat tidak boleh menghadap pada tempat yang disakralkan yakni hutan keramat. Hal ini tertuang dalam Pasang yang berbunyi "Naiya bolaya ri tana kamase-mase tanakulle nadalleki borong karasayya, tanakulle nadalleki allu mannyallukia, naiya kulle dihoja passiringanga" yang artinya rumah dalam kawasan adat tidak boleh menghadap ke hutan keramat dan lembah yang dalam, sehingga perlu dilihat tempat yang tepat. Orientasi rumah yang cenderung menyamping dari hutan keramat merupakan salah satu upaya untuk menjaga kelestarian hutan. Rumah-rumah yang menghadap langsung ke hutan keramat dikhawatirkan dapat menimbulkan perubahan perilaku masyarakat untuk mengubah atau merusak hutan, karena tergiur nilai-nilai ekonomi dan sumber daya alam yang terkandung dalam hutan keramat tersebut.

\section{Landuse dan Aktivitas}

Karakter landuse pada lanskap budaya Masyarakat Adat Kajang dapat diidentifikasi dari peta buatan Belanda tahun 1943 (Gambar 3). Berdasarkan peta tersebut, dapat diketahui bahwa pada tahun 1943-an setelah kedatangan bangsa Belanda tipe lanskap budaya Masyarakat Adat Kajang masih berbasis pada pertanian yaitu sawah. Seiring dengan perkembangan zaman dan aktivitas masyarakat yang bergerak dinamis, penggunaan lahan di kawasan lanskap budaya Masyarakat Adat Kajang mengalami perubahan. Saat ini lahan kebun/ladang merupakan area yang paling dominan (Gambar 4).

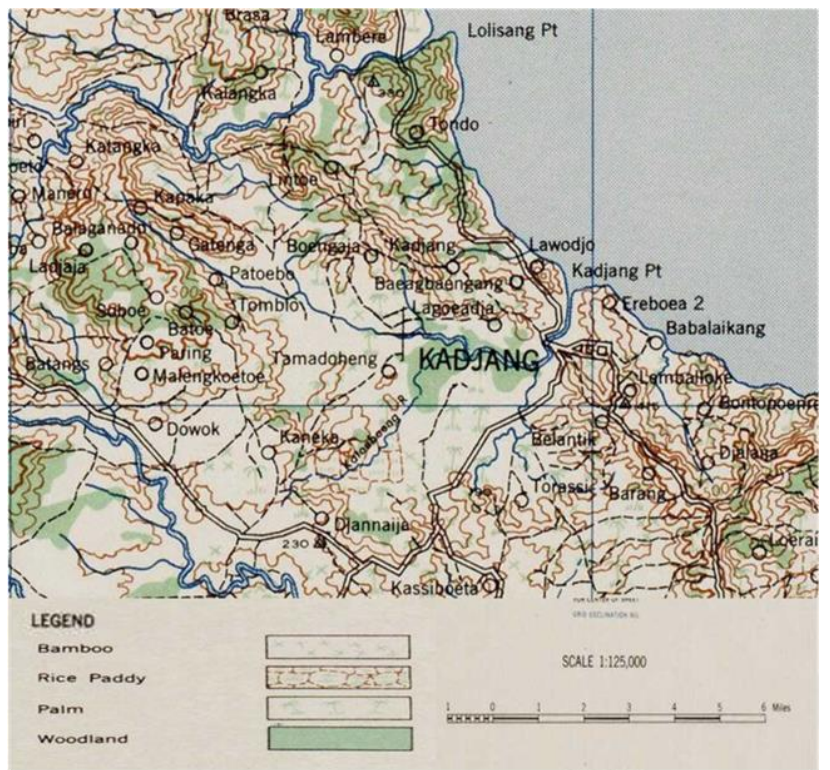

Sumber: http://maps.library.leiden.edu

Gambar 3. Landuse Kecamatan Kajang Tahun 1943

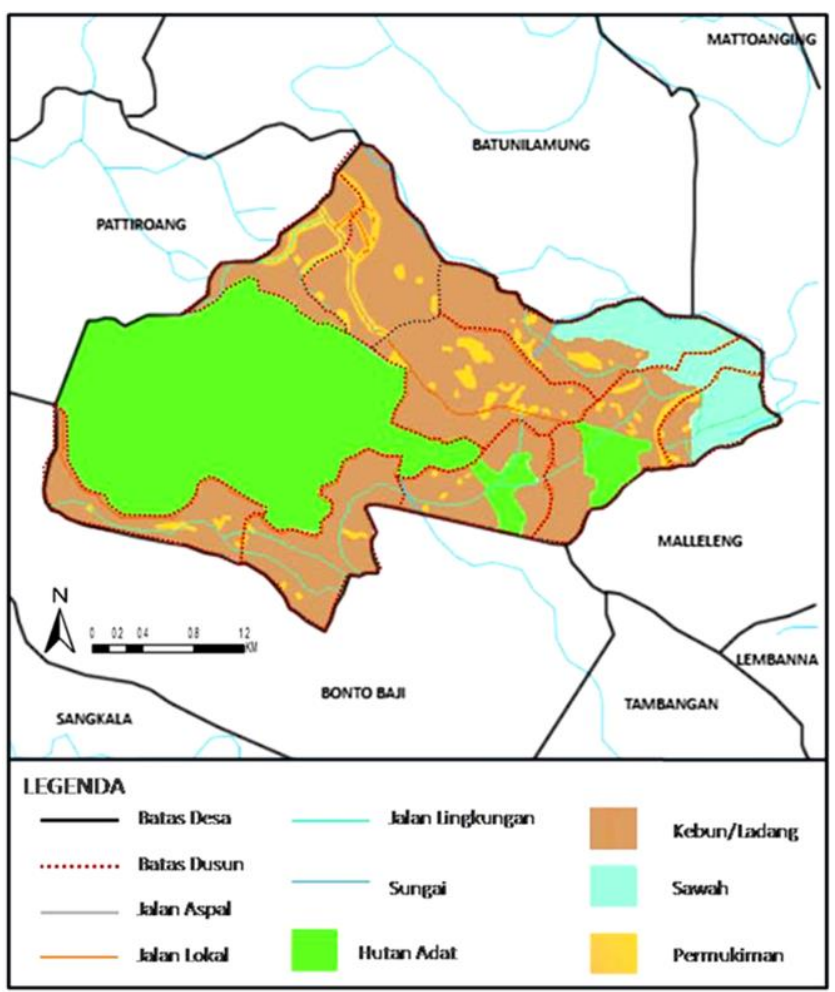

Gambar 4. Landuse lanskap budaya Masyarakat Adat Kajang 
AWALIA, NURHAYATI, KASWANTO

Masyarakat Adat Kajang umumnya dikenal hidup melalui mata pencaharian bertani yang sudah dilakukan secara turun-temurun. Kegiatan bertani dan berkebun dalam kawasan adat meperhatikan bentang alam agar hasil produksi baik dan alam tetap terjaga. Pemanfaatan lahan untuk pertanian diatur dalam Pasang yang berbunyi "punna donro koko, punna lappara galung" artinya jika lahan berbukit cocok untuk kebun, jika lahannya datar cocok untuk sawah.

\section{Cluster}

Clusters merupakan kelompok bangunan, struktur, objek atau fitur lainnya yang terdapat pada area-area tertentu seperti pertanian atau permukiman. Pada lanskap budaya Masyarakat Adat Kajang yang memiliki pola mengelompok berupa cluster adalah permukiman. Area permukiman pada lanskap ini terbagi menjadi dua kelompok yaitu permukiman masyarakat kamase-mase yang terletak di Kajang Dalam dengan luas 384 ha dan permukiman masyarakat kuasayya yang terletak di Kajang Luar dengan luas 72 ha. Cluster pada lanskap budaya ini memiliki perbedaan yang jelas berdasarkan aktivitas budaya dan kepatuhan terhadap norma/aturan adat. Komunitas yang bermukim dalam kawasan Kajang Dalam lebih teguh memegang adat dan tradisi nenek moyang mereka dibandingkan komunitas yang bermukim di kawasan Kajang Luar. Kedua kelompok permukiman tersebut memiliki pola yang berbeda. Kelompok bangunan pada kawasan Kajang Dalam memiliki pola mengelompok berdasarkan sistem kekerabatan. Sedangkan permukiman pada kawasan Kajang Luar memiliki pola memanjang mengikuti jalan yang dibangun (Gambar 5).

\section{Pola Organisasi Ruang}

Masyarakat Adat Kajang membagi ruangnya menjadi tiga bagian yang disebut dengan pola tripatri. Pola tripatri ini terbentuk dari pola hidup masyarakat yang bergantung penuh pada alam (Erawati 2016). Pola tripatri pada lanskap budaya Masyarakat Adat Kajang dapat dilihat pada pembagian wilayah. Masyarakat Adat Kajang membagi wilayahnya menjadi tiga bagian yaitu wilayah suci/sakral, wilayah semi sakral, dan wilayah profan (Gambar 6). Wilayah sakral merupakan wilayah yang tidak boleh dikunjungi oleh sembarang orang yang terletak di Dusun Benteng. Di wilayah ini terdapat tiga area yang disakralkan yaitu hutan keramat, makam leluhur, dan area rumah Ammatoa. Wilayah semi sakral merupakan area permukiman masyarakat kamasemase. Selain bangunan rumah tradisional, di kawasan ini juga terdapat hutan, makam masyarakat kamase-mase, dan balla tammua. Sedangkan wilayah profan adalah kawasan yang berada di luar wilayah adat (Kajang Luar) yang masyarakatnya sudah mulai meninggalkan norma/aturan adat dan ajaran leluhur mereka.

Selain membagi wilayahnya menjadi tiga bagian (pola tripatri), Masyarakat Adat Kajang juga menetapkan

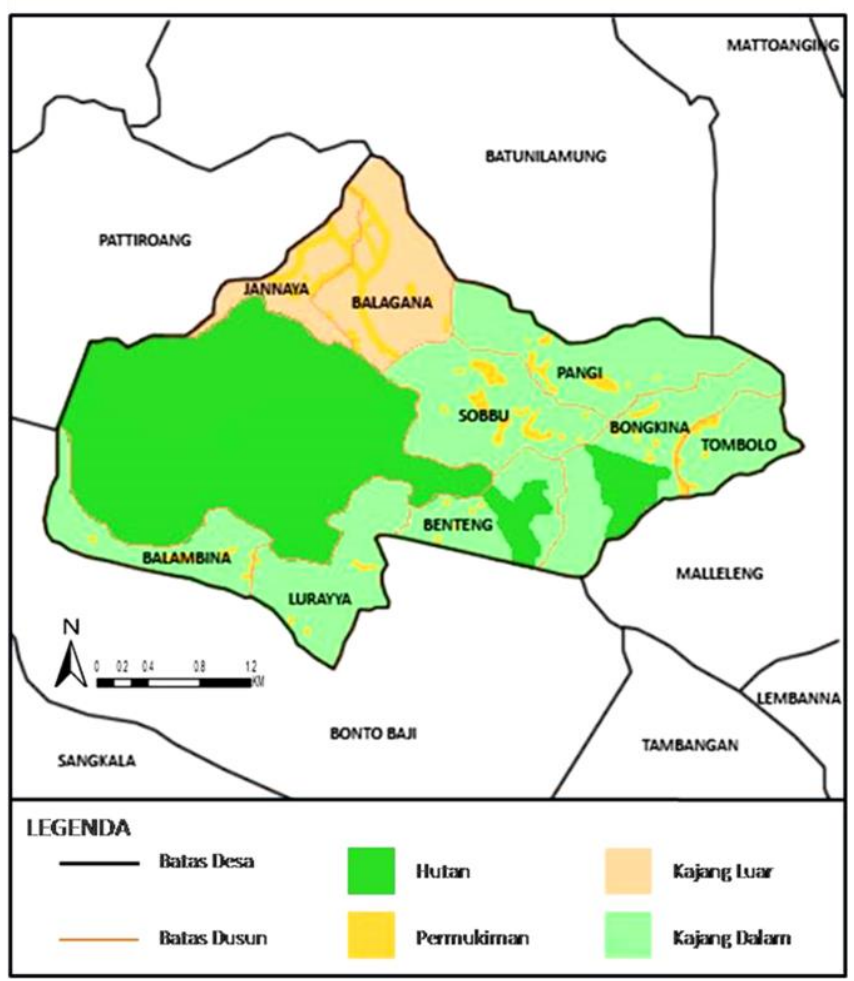

Gambar 5 Cluster berdasarkan karakter permukiman

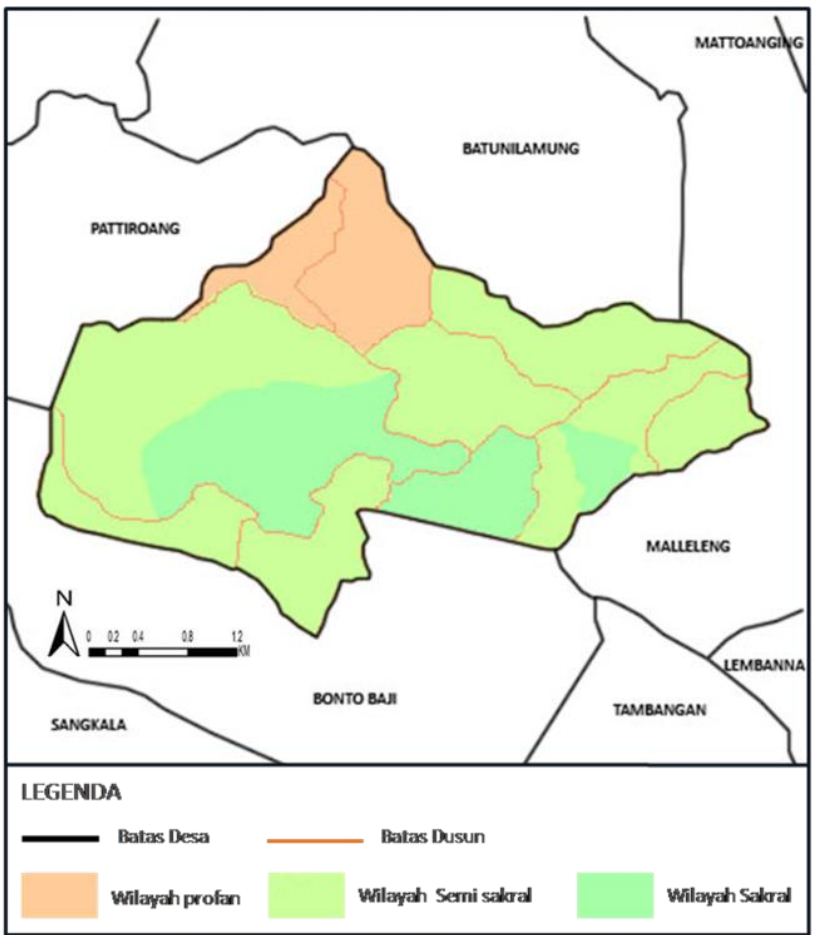

Gambar 6. Pembagian wilayah lanskap budaya Kajang 
AWALIA, NURHAYATI, KASWANTO

wilayah hutannya dalam tiga zona, yaitu Borong Karamaka (hutan keramat) yang merupakan kawasan terlarang untuk semua jenis kegiatan, terkecuali kegiatan ritual adat. Borong Batasayya (hutan perbatasan) yang diperbolehkan diambil kayunya untuk membangun rumah dengan seizin dari Ammatoa, dan Borong Luarayya (hutan rakyat) yang bisa dikelola oleh masyarakat tapi tetap meperhatikan aturan adat (Gambar 7).

Pola tata ruang tripatri juga dapat dilihat pada tatanan terkecil dari lanskap budaya Masyarakat Adat Kajang yaitu rumah tradisional Kajang. Secara vertikal dan horisontal rumah tradisional Kajang terbagi menjadi tiga bagian yang bertingkat. Secara vertikal terdiri atas ruang bawah (huribola)/Siring (kolong rumah) berfungsi sebagai tempat menyimpan peralatan pertanian, menumbuk padi, menenun, serta untuk kandang ternak. Ruang tengah (alebola)/Kale balla (Badan rumah) berfungsi sebagai tempat tinggal penghuni rumah, dan ruang atas (ulubola) yang biasa disebut Para berfungsi untuk menyimpan benda-benda pusaka seperti keris dan benda-benda peninggalan nenek moyang mereka. Secara horisontal struktur/ruang rumah tradisonal Kajang terdiri atas ruang depan (latta riolo) yang digunakan sebagai dapur dan ruang tamu, ruang tengah (Latta tangaga) digunakan untuk ruang makan, dan juga ruang tidur untuk anggota keluarga, ruang belakang (latta ri boko/tala-tala) menjadi ruang kepala keluarga dan dibatasi oleh dinding papan atau bambu (Gambar 8).

\section{Jaringan Sirkulasi}

Dalam kawasan adat terdapat dua tipe jalan yaitu jalan lokal dan jalan lingkungan (Gambar 9). Jalan lokal merupakan jalan utama yang menghubungkan antara kawasan Kajang Luar dan kawasan Kajang Dalam. Sedangkan jalan lingkungan adalah jalan penghubung antar dusun di dalam kawasan adat. Jenis konstruksi untuk jalan lokal berupa jalan berbatu sedangkan jalan lingkungan masih berupa pengerasan, setapak, dan tanah. Konstruksi perkerasan sepanjang $15 \mathrm{~km}$, jalan tanah $10 \mathrm{~km}$, dan jalan setapak $15 \mathrm{~km}$. Lebar jalan sekitar 2-3 meter dengan kedua sisi (bahu jalan) untuk dilalui kuda/kerbau dan badan (tengah jalan) untuk jalur pejalan kaki/orang. Akses masyarakat yang bermukim dalam kawasan adat dilakukan dengan berjalan kaki. Saat ini ada dua akses keluar masuk lanskap budaya Masyarakat Adat Kajang, yang pertama melalui Desa Malleleng menuju Dusun Tombolok dan yang kedua melalui kawasan Kajang Luar menuju Dusun Sobbu. Kedua akses ini saling berhubungan dan membentuk jalur yang melewati kawasan adat (Gambar 10).

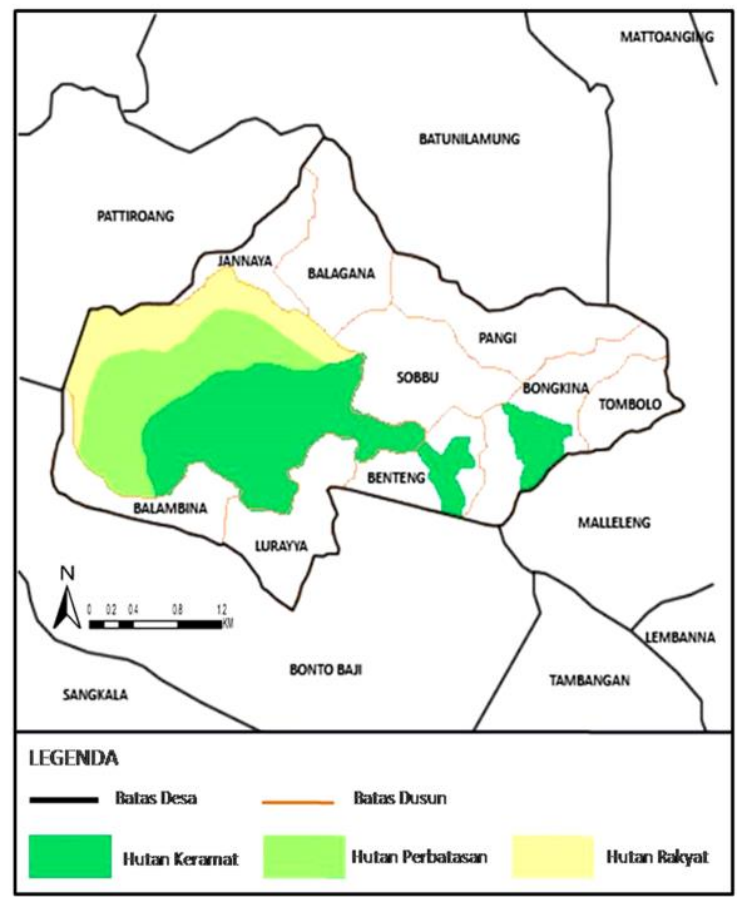

Gambar 7. Zonasi hutan

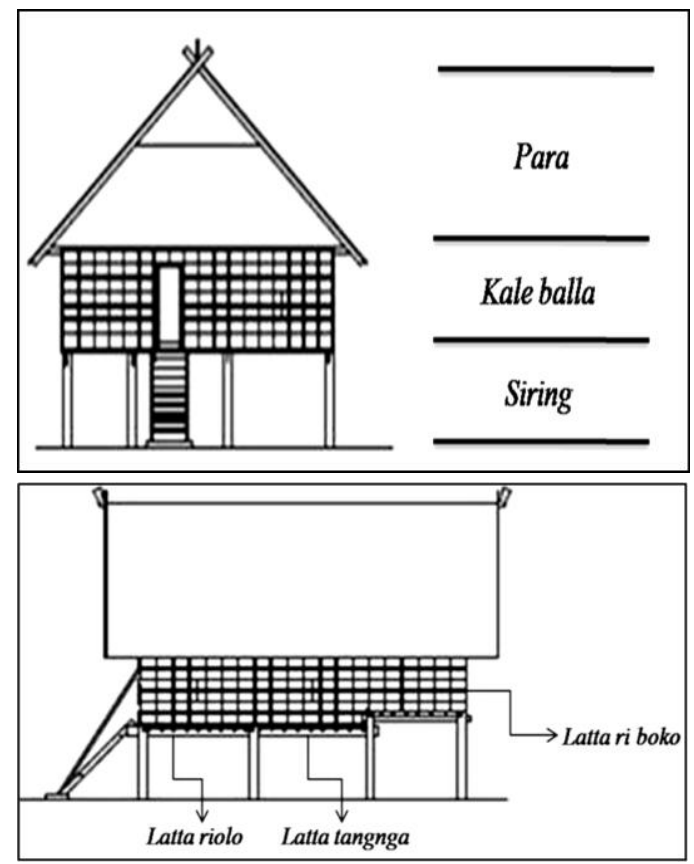

Sumber: Heryati (2011)

Gambar 8 Pembagian ruang rumah secara vertikal (atas) dan horisontal (bawah) 


\section{Vegetasi}

Terdapat beberapa tanaman yang memiliki peran penting bagi Masyarakat Adat Kajang, diantaranya adalah bitti (Vitex cofassus), nipa (Nypa fruticans), bambu (Bambusa Sp), rotan (Callamus rotang), dan tarum (Indigofera suffruticosa). Kayu bitti digunakan sebagai

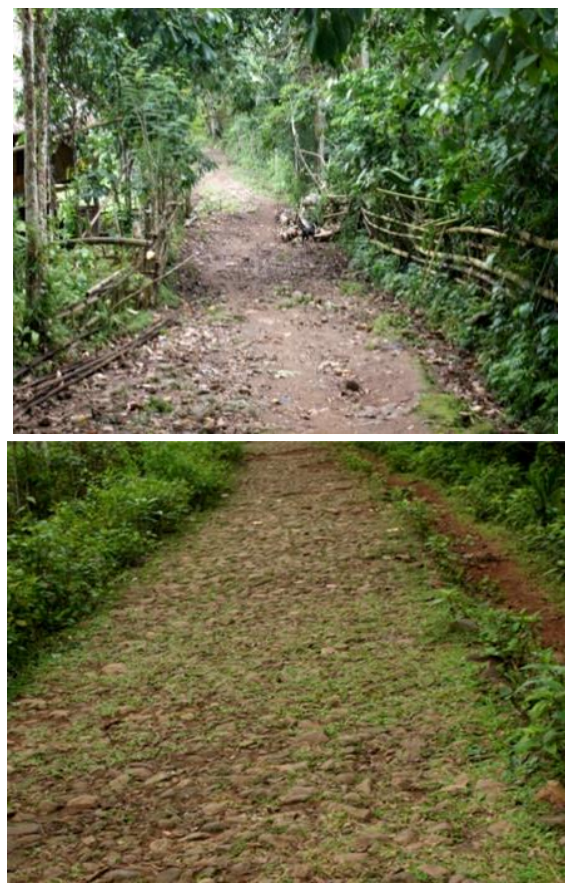

Sumber: Dokumentasi (2015)

Gambar 9 Tipe jalan dalam kawasan adat

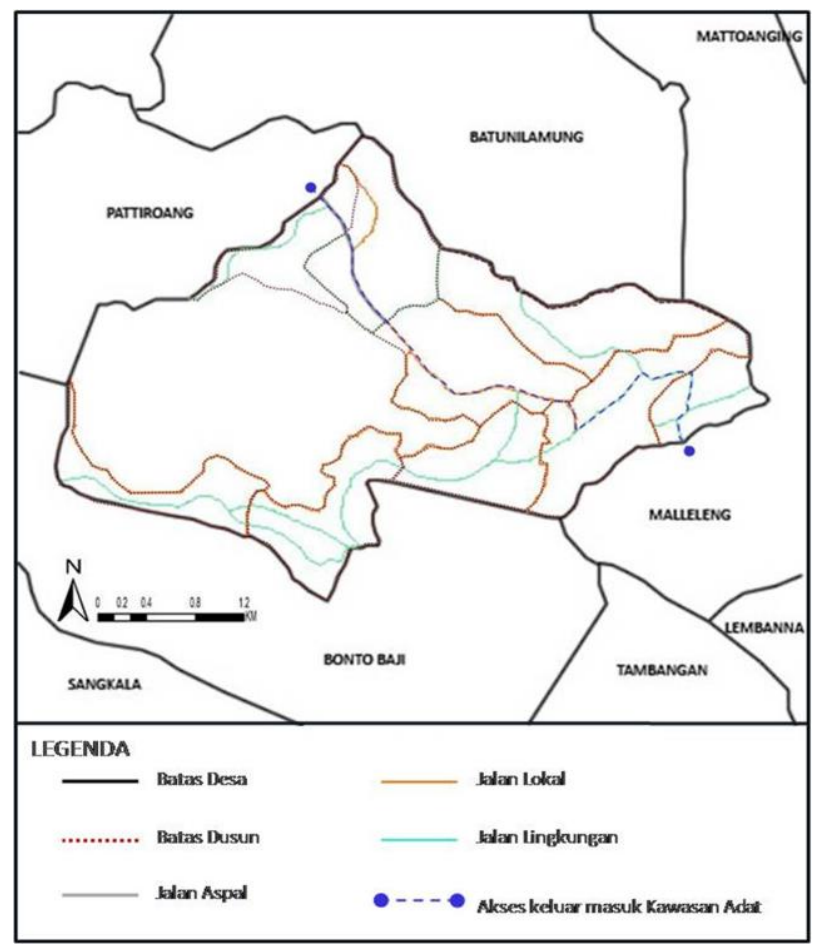

Gambar 10 Jaringan sirkulasi tiang rumah, daun nipa digunakan untuk membuat atap rumah, bambu digunakan untuk membuat lantai dan dinding rumah, rotan digunakan untuk mengikat tiangtiang rumah, sedangkan daun tarum digunakan sebagai bahan dasar pewarna kain/benang yang akan digunakan untuk menenun. Masyarakat Adat Kajang juga memanfaatkan buah pinang dan daun sirih sebagai tanaman pelengkap dalam prosesi upacara/ritual adat. Selain sebagai bahan bangunan, pewarna kain, dan pelengkap upacara/ritual adat, terdapat beberapa jenis tanaman yang digunakan Masyarakat Adat Kajang dalam kehidupan sehari-hari seperti kelapa (Cocos nucifera), lontar (Borassus flabellifer), buah maja (Aegle marmelos), kemiri (Aleurites moluccana). Tempurung kelapa sebagai alat untuk dipakai minum, lontar digunakan untuk membuat piring, buah maja digunakan sebagai tempat atau wadah air minum, dan kemiri digunakan sebagai bahan dasar pembuatan minyak untuk penerangan (lampu). Selain itu terdapat juga beberapa jenis tanaman yang dimanfaatkan sebagi tanaman obat diantaranya temulawak (Curcuma zanthorrhiza) dan jambu biji (Psidium guajava) untuk pengobatan sakit perut (diare), daun jarak (Ricinus communis) untuk pengobatan demam dan daun pisang (Musa sp.) untuk pengobatan perempuan yang telah bersalin.

\section{Bangunan dan Struktur}

Bangunan dan struktur yang memiliki karakter yang khas dan bernilai penting pada lanskap budaya Masyarakat Adat Kajang terdiri atas rumah tradisional dan Balla Tammua (Gambar 11). Bentuk dasar dari rumah tradisional Kajang yaitu berbentuk persegi panjang dengan jumlah tiang 16 buah yang terdiri dari 4 baris. Rumah tradisional Kajang memiliki ornamen berupa Anjong yang terdapat pada bubungan rumah dan kepala kerbau pada benteng tangnga (tiang utama). Penggunaan kepala kerbau pada rumah tradisonal Kajang hanya sebagai simbol dan penanda bahwa si penghuni rumah sudah ada yang meninggal dan menikah.

Balla Tammua merupakan salah satu produk arsitektur warisan leluhur yang masih bisa ditemui hingga saat ini. Peninggalan ini merupakan bangunan tempat pertemuan Masyarakat Adat Kajang untuk mengadakan musyawarah yang dalam bahasa Konjo disebut borong/abborong. Biasanya para pemangku adat melakukan abborong di Balla Tammua untuk membahas permasalahan yang ada di kawasan adat. Menurut Arifin (2103), balla tammua lebih berfungsi sebagai teritori karena lebih sering tidak termanfaatkan.

Struktur lainnya yang membentuk karakter lanskap budaya Masyarakat Adat Kajang adalah makam leluhur (Gambar 12). Makam yang dimaksud adalah makam tunggal (kuburu tunggalaka), makam ini berada di dalam hutan keramat dan dijadikan sebagai area yang sakral bagi Masyarakat Adat Kajang. Pada area permukiman 
AWALIA, NURHAYATI, KASWANTO

inti juga ditemukan makam yang masih memiliki struktur seperti jirat yaitu makam Galla Puto Beceng yang lahir pada tahun 1908 dan wafat pada tahun 2008.

\section{Situs Arkeologi}

Pada lanskap budaya Masyarakat Adat Kajang ditemukan situs arkeologi berupa batu temu gelang dan batu menhir (Gambar 13). Batu temu gelang berada di dalam hutan keramat dan berfungsi sebagai tempat pelantikan Ammatoa dan sebagai tempat berkumpulnya para pemangku adat untuk mendengarkan penuturan Pasang dari calon Ammatoa. Batu temu gelang ini merupakan susunan batu berbentuk pipih tanpa perekat.
Menurut kepercayaan Masyarakat Adat Kajang, batu ini merupakan tempat turunnya tau mariolo (orang pertama). Batu ini sudah ada sejak periode pemerintahan Raja Gowa ke IV dan V. Sementara batu menhir ditemukan pada makam-makam leluhur, batu menhir tersebut berupa batu berbentuk lonjong atau persegi yang ditanam di atas makam dengan posisi tegak berdiri sebagai batu nisan atau penanda makam.

\section{Elemen Skala Kecil}

Karakter sebuah lanskap budaya juga tidak terlepas dari elemen skala kecil yang memiliki kaitan erat dengan berbagai aktivitas kehidupan serta budaya masyarakat.

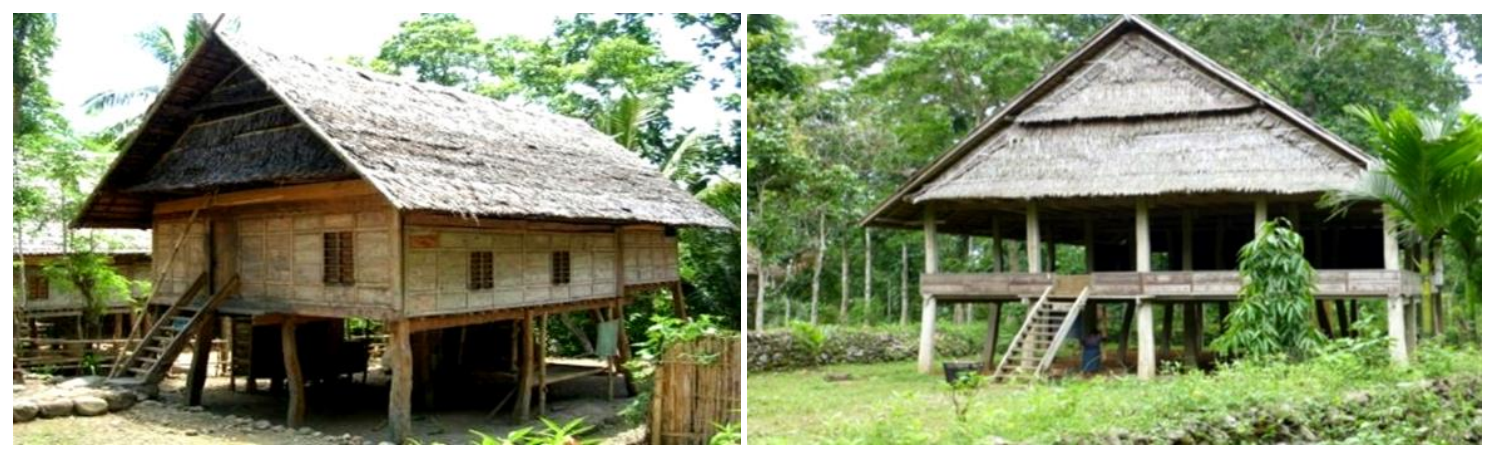

Sumber: Dok. Pribadi (2015)

Gambar 11 Struktur rumah tradisional (kiri) dan balla tammua (kanan)
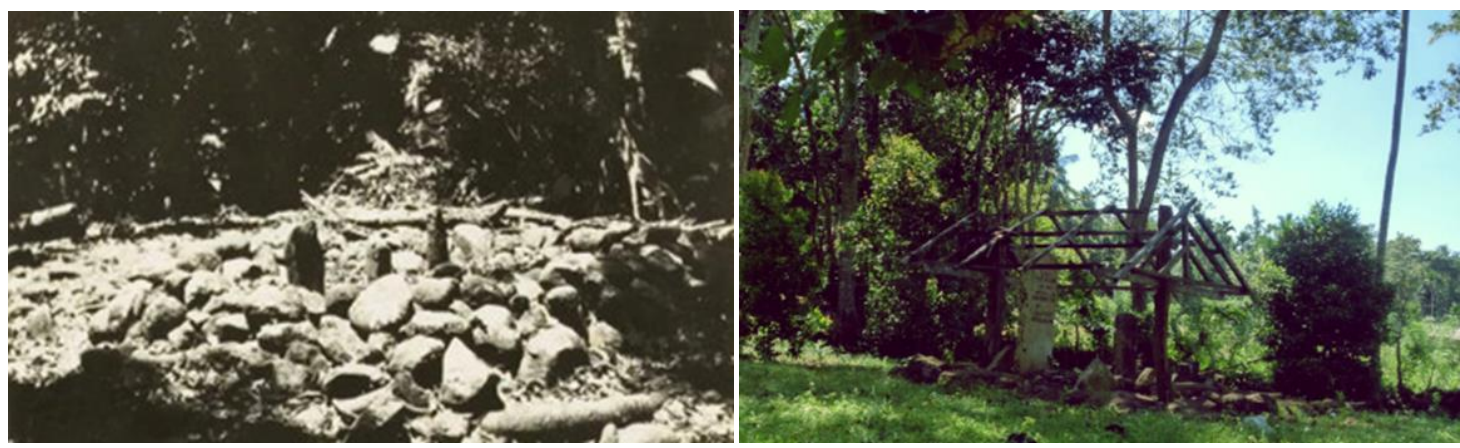

Sumber: http//www.media-kitlv.nl (2016) dan https:/ /lintasbudayaid.wordpress.com (2016)

Gambar 12 Makam leluhur: makam tunggal (kiri) dan makam Galla Puto Beceng (kanan)
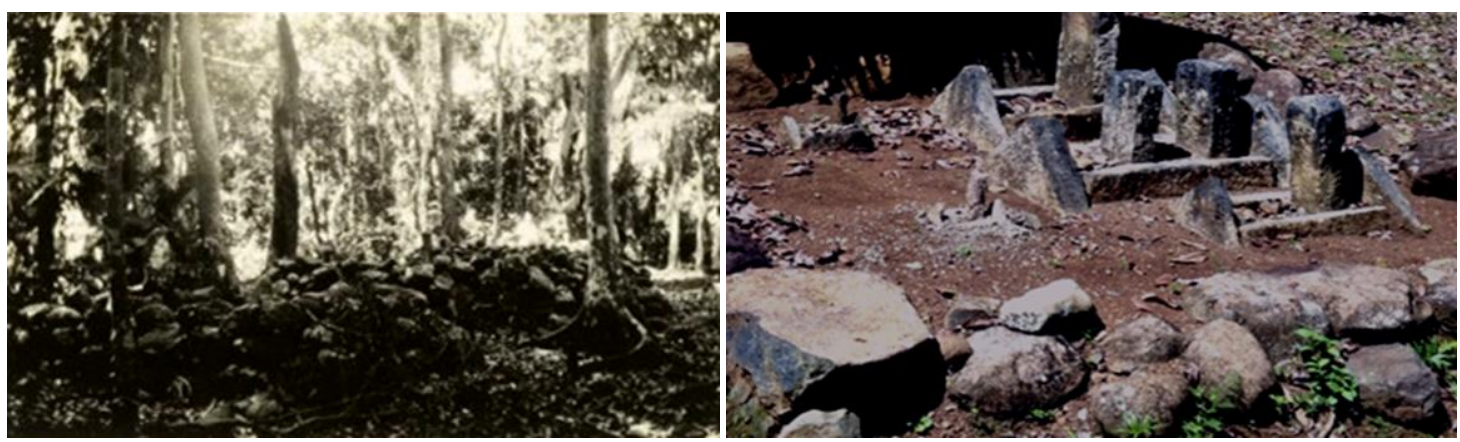

Sumber: http// www.media-kitlv.nl (2016) dan Dok. Pribadi (2016)

Gambar 13 Batu temu gelang (kiri) dan batu menhir pada makam leluhur (kanan) 
AWALIA, NURHAYATI, KASWANTO

Elemen skala kecil yang dapat dijumpai pada lanskap budaya Masyarakat Adat Kajang berupa kamar mandi umum dan pagar batu (Gambar 14). Kamar mandi umum ini terletak di Dusun Sobbu, sekitar 500 meter dari pintu gerbang masuk kawasan adat. Kamar mandi umum ini merupakan satu-satunya kamar mandi umum di dalam kawasan adat yang digunakan Masyarakat Adat Kajang untuk mandi, mencuci baju, untuk kebutuhan sehari-hari/keperluan rumah tangga lainnya, serta untuk memandikan ternak. Sedangkan pagar batu berfungsi sebagai pembatas antara halaman/pekarangan rumah dengan jalan. Tinggi pagar batu adalah $135 \mathrm{~cm}$, tebal bagian atas $70 \mathrm{~cm}$, dan tebal bagian bawah adalah $110 \mathrm{~cm}$. Penyusunan pagar batu ini tidak menggunakan perekat, hanya merupakan tumpukan batu andesit yang ditata sedemikian rupa hingga membentuk sebuah pagar. Pada pagar batu ini terdapat pintu yang lebarnya 1,5 meter yang letaknya berada di tengah-tengah. Pintu pagar yang digunakan berupa palang kayu atau bambu. tradisional Kajang dibagi menjadi tiga bagian baik itu secara vertikal maupun horisontal. Secara vertikal terdiri atas huribola (kolong rumah), alebola (badan rumah), dan ulubola (bagian atas). Sedangkan secara horisontal dibagi menjadi latta riolo (ruang tamu), latta tangnga (ruang keluarga), dan latta ri boko/tala-tala (ruang tidur). Sedangkan area kawasan hutan dibagi menjadi borong karamaka (hutan keramat), borong batasayya (hutan perbatasan), dan borong luarayya (hutan rakyat).

Masyarakat Adat Kajang membagi wilayahnya menjadi tiga bagian yaitu wilayah sakral, semi sakral, dan profan. Wilayah sakral berada pada area kawasan Kajang Dalam. Masyarakat yang bermukim di wilayah ini masih memegang teguh norma/aturan adat. Pada wilayah ini terdapat beberapa elemen lanskap yang masih asli makam leluhur, batu temu gelang, rumah Ammatoa, dan kamar mandi umum. Wilayah semi sakral juga merupakan bagian dari area kawasan Kajang Dalam, pada wilayah ini terdapat balla tammua dan rumah tradisional yang masih asli. Wilayah profan berada pada
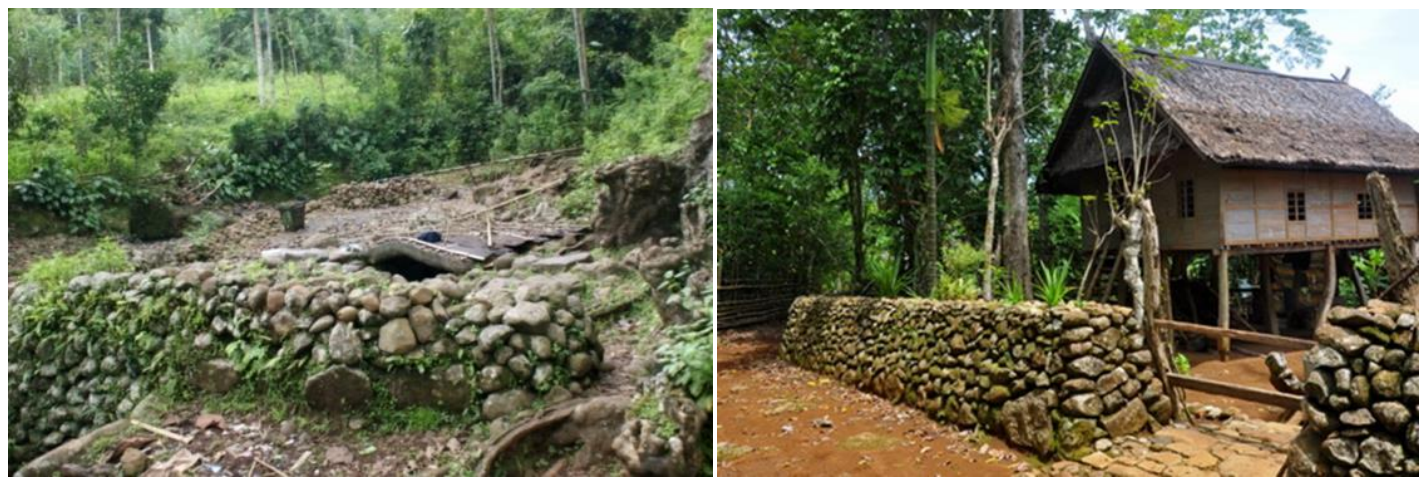

Sumber: Dok. Pribadi (2016)

Gambar 14 Sumur umum (kiri) dan pagar batu (kanan)

\section{Tipe dan Area Karakter Lanskap}

Berdasarkan hasil analisis terhadap sebelas karakteristik lanskap pada lanskap budaya Masyarakat Adat Kajang, maka dilakukan karakterisasi. Karakterisasi pada lanskap budaya Masyarakat Adat Kajang menghasilkan peta dan deskripsi karakter lanskap. Berdasarkan hasil karakterisasi diketahui bahwa tipe karakter lanskap budaya Masyarakat Adat Kajang adalah lanskap permukiman tradisional dengan pola tata ruang tripatri berbasis pada sumber daya alam lokal (hutan dan lahan pertanian) yang masyarakatnya menganut sistem kepercayaan Patuntung (Gambar 15).

Pola tripatri pada lanskap budaya Masyarakat Adat Kajang terbentuk karena kebiasaan Masyarakat Adat Kajang membagi ruangnya menjadi tiga bagian, baik itu secara makro maupun secara mikro. Pola Tripatri pada lanskap budaya Masyarakat Adat Kajang dapat dilihat pada pembagian wilayah, zonasi hutan, dan pembagian struktur/ruang rumah. Struktur/ruang rumah area kawasan Kajang Luar yang masyarakatnya sudah mulai meninggalkan norma/aturan adat. Rumah-rumah tradisional di wilayah ini sebagian besar sudah mengalami perubahan material, bentuk dan letak. Perubahan pola permukiman pada area ini mengikuti pola jalan aspal yang dibangun.

Pola tripatri pada lanskap budaya Masyarakat Adat Kajang tidak hanya pada pembagian ruang, tapi juga dapat dilihat pada pandangan dunia dan sanksi pelanggaran adat. Masyarakat Adat Kajang memiliki tiga pandangan dunia yaitu dunia atas, dunia tengah, dan dunia bawah. Dunia atas menempati tanah yang sakral/tanah larangan yang di dalamnya terdapat hutan keramat. Dunia tengah menempati wilayah permukiman kamase-mase, tempat Masyarakat Adat Kajang melakukan aktivitas sehari-hari. Dunia bawah menempati wilayah permukiman kuasayya, tempat dimana masyarakat sudah mulai meninggalkan aturan adat. 


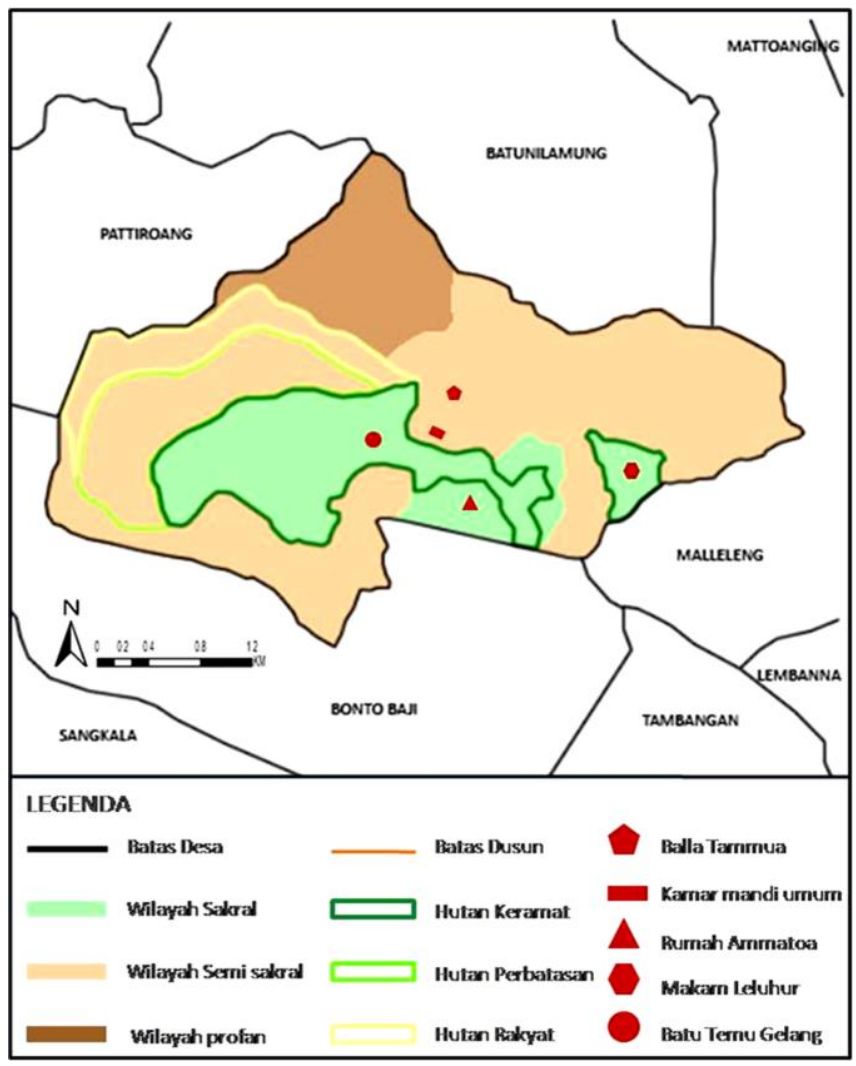

Gambar 15. Peta Karakter Lanskap

Karakter lanskap mengacu pada area dengan fitur yang unik dan memiliki ciri khas tersendiri yang membedakannya dengan area lainnya (Wang dan $\mathrm{Yu}$ 2012). Wilayah sakral adalah bagian dari lanskap budaya Masyarakat Adat Kajang yang memiliki karakteristik unik yang masih kuat. Wilayah sakral adalah bagian dari lanskap budaya Masyarakat Adat Kajang yang memiliki karakteristik unik yang masih kuat. Unit lanskap yang menunjukkan karakter kuat adalah area permukiman sakral, hutan keramat, dan elemen-elemen lanskap yang berada disekitar permukiman yaitu makam leluhur, batu temu gelang, balla tammua, dan kamar mandi umum.

\section{KESIMPULAN}

Hasil analisis terhadap 11 elemen pembentuk karakter lanskap menunjukkan bahwa tipe karakter lanskap budaya Masyarakat Adat Kajang adalah lanskap permukiman tradisional dengan pola tata ruang tripatri berbasis pada sumber daya alam lokal (hutan dan lahan pertanian) yang masyarakatnya menganut sistem kepercayaan Patuntung. Pola tripatri pada lanskap budaya Masyarakat Adat Kajang dapat dilihat pada pembagian wilayah, zonasi hutan, dan pembagian struktur/ruang rumah. Unit lanskap yang menunjukkan karakter kuat adalah area permukiman sakral, hutan keramat, dan elemen-elemen lanskap yang berada disekitar permukiman yaitu makam leluhur, batu temu gelang, balla tammua, dan sumur umum.

\section{DAFTAR PUSTAKA}

Arifin M. 2013. Ruang Hunian dalam Perspektif Komunitas Ammatoa Kajang Sulawesi Selatan. Temu Ilmiah IPLBI. Makassar. 12 - 13 November 2013.

Erawati, E. 2016. Pola Permukiman Tradisional Kajang. Kapata Arkeologi. 8 (2): 47-162. Maluku: Balai Arkeologi Maluku.

Erawati, E. 2016. Tipe Kawasan Kajang: Dari Ruang Agraris ke Ruang Maritim. Prosiding Seminar Antarbangsa Arkeologi, Sejarah, Budaya, dan Bahas di Alam Melayu Nusantara (ASBAM) V. Makassar. 26 27 juli 2016.

Heryati. 2011. Menguak Nilai-Nilai Tradisi pada Rumah Tinggal Masyarakat Ammatoa-Tanatoa Kajang di Sulawesi Selatan. Jurnal Inovasi. 8 (4): 1541-1557. Gorontalo: Universitas Negeri Gorontalo.

McClelland L, Keller L, Keller G, Melnick R. 1999. Guidelines for evaluating and documentating rural historic landscapes. National Register Bulletin. [internet]. [diunduh 2015 Februari 10]. Tersedia pada: http://www.nps.gov/history/nr/publications/bull etins $/ \mathrm{nrb30/}$.

Palengkahu RA. 1971 Dialek Konjo di Sulawesi Selatan. Ujungpandang: Lembaga Bahasa Nasional.

Tudor C. 2014. An Approach to Landscape Character Assessment. England: Natural Engaland.

Wang M, Yu B. 2012. Landscape Characteristic Aesthetic Structure: Construction of Urban Landscape Characteristic Time-Spatial Pattern Based on Aesthetic Subjects. Frontiers of Architectural Research. 1 (3): 305-315. 